\title{
Paleoclimatic and stratigraphic significance of Belgrandia marginata (Michaud) in Late Quaternary malacofauna of Belarus and Lithuania
}

\author{
Aleksander Sanko $^{\mathrm{a}, *}$, Algirdas Gaigalas ${ }^{\mathrm{b}, 1}$, Yadviga Yelovicheva ${ }^{\mathrm{c}}$ \\ ${ }^{a}$ Department of Natural History, Belarus State Pedagogical University, Sovetskaya 18, 220030 Minsk, Belarus \\ ${ }^{\mathrm{b}}$ Department of Geology and Mineralogy, Vilnius University, Čiurlionio 21/27, LT-03101 Vilnius, Lithuania \\ ${ }^{\mathrm{c}}$ Geography Department, Belarusian State University, Minsk Belarus Independence Prospectus, 4, Minsk 220050, Belarus
}

\section{A R T I C L E I N F O}

\section{Article history:}

Available online $\mathrm{xxx}$

\begin{abstract}
A B S T R A C T
The fauna and flora of each Quaternary interglacial epoch of the middle latitudes possesses general and specific connections with climate. The presence of the Atlantic and West European mollusc Belgrandia marginata (Michaud) is distinctive in the freshwater malacofauna of the Eemian (Muravian, Merkine) interglacial in Belarus, Lithuania, and Poland. This species is present in eight malacofaunas of the region, with exclusively Eemian age. Paleontologic researches show that the species occupied reservoirs in this territory only during an optimum Eemian interglacial, giving it stratigraphical value in the region. The $1000 \mathrm{~km}$ sublatitudinal extent of the species through the Central European plain and Russian plain to the Dnieper River reflects, most likely, the direction of circulation of Atlantic air masses deep into the continent. The Eemian extent of B. marginata in the upstream Dnieper basin is imposed on the range of the Ponto-Caspian mollusc Dreissena polymorpha, which also occupied the upstream Dnieper basin only in the Eemian Interglacial. Both species are characteristic representatives of the Eemian (Muravian) freshwater malacofauna of Belarus.
\end{abstract}

(c) 2011 Elsevier Ltd and INQUA. All rights reserved.

\section{Introduction}

Quaternary research associated with INTAS-01-0675 has allowed active geological, geochronological and malacological study of the main sections in Belarus and Lithuania. One result of this work was the recognition of the palaeoclimate and stratigraphic significance of the Quaternary exotic mollusc Belgrandia marginata (Michaud).

Finds of rare shells and those unknown in a certain region, as well as other palaeontological remains, always excite the interest of specialists, as they expand the variety of species, enable more detailed palaeogeographic reconstructions and, in some cases, help to correlate buried beds. $B$. marginata is one such find. The presentday habitat of this western European mollusc does not reach the area of Lithuania, Belarus, and East Europe. However, during the Quaternary Eemian Interglacial, its habitat expanded eastwards. It was detected at first in the malacofauna of Poland (Niezabitowski, 1929; Skompski, 1983) and later in Belarus (Sanko, 2004). It is natural that similar findings among the molluscs in Lithuania are also possible (Sanko and Gaigalas, 2007).

\footnotetext{
* Corresponding author.

E-mail addresses: sankoaf@tut.by(A.Sanko),yelovicheva@land.ru(Y.Yelovicheva). 1 Deceased.
}

The malacological characteristics of sediments of the Lithuanian and Belarus sections with this Interglacial exotic (Fig. 1) are presented here. Conditions of formation of sediments and mollusc fauna, including palaeoclimate, stratigraphy, and ecology, are discussed.

\section{Characterisation of species}

The shell (Fig. 2) is small (to $2.5 \mathrm{~mm}$ height, $1.1 \mathrm{~mm}$ width). Therefore it is difficult to determine specimen ages. The shell is conic with dim cross lines (striated). The first 1.5-2 whorls are not striated, with dimple texture seen at high enlargement. There are 4.5 whorls, convex and gradually increasing, more low than broad. Its aperture is round-oval, sometimes egg-shaped or slightly square at the top. At the outer side of the aperture there is a characteristic digitate roughness parallel to the aperture margin. Niezabitowski (1929) observed up to three such riblets on the shells taken from the Eemian deposits in Poland. Shells from the Szelong section at Poznan also had a shorter whorl, and the author proposed to consider it as a variety of Belgrandia marginata polonica.

The species discussed belongs to a group of West European Atlantic molluscs. Its habitat is in the rivers of France and Catalonia. During the Pleistocene interglacials, it widened its area into Central Europe. It was rather widely distributed in the Waalian, Cromerian and Holsteinian interglacials in northern Europe, including the 


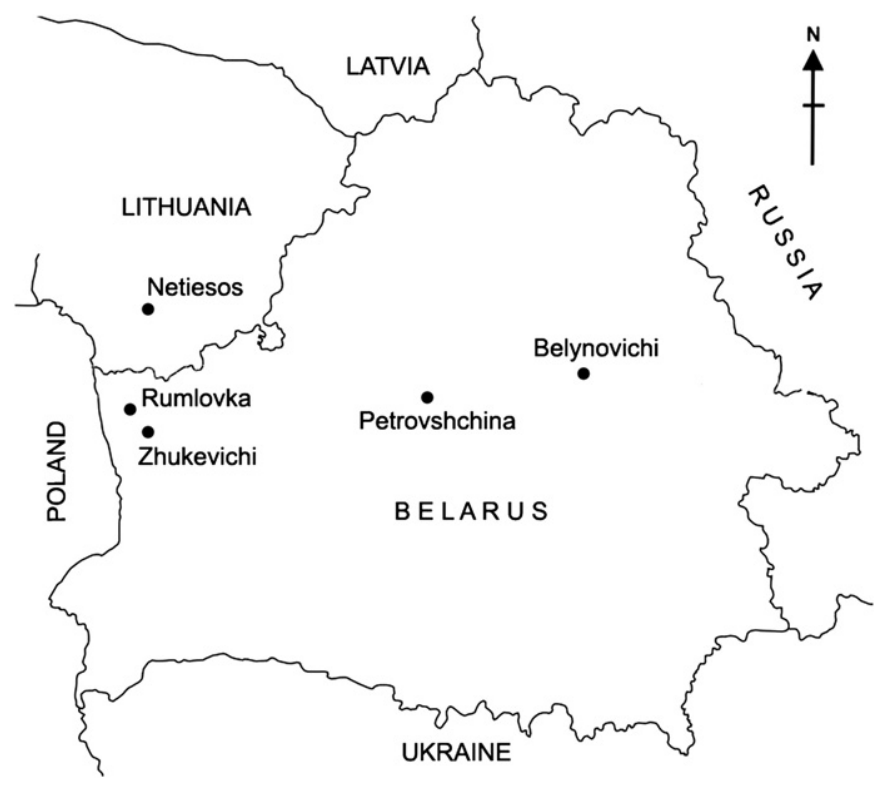

Fig. 1. Location of sections discussed in the text.

Rhine basin (Meijer and Preece, 1996). During the optimum of the Eemian, the habitat of the species covered the area of Great Britain, Denmark, Germany, and Poland. The regions of Belarus and Lithuanian seem to be the easternmost and northernmost margins of the habitat. A total of 39 shells of this species were detected in the Muravian interglacial deposits, borehole Tl-48 near the town of Belynichi (Sanko, 2004). In Zhukevichi at Neiman and in Netiesos (Lithuania), only 1 shell was found, in Rumlovka near Grodno 3 shells, and in Petrovshchina (Minsk), 125 shells of this species was found.

\section{Malacofauna at Netiesos (Lithuania)}

The interglacial deposits in the Netiesos outcrop are considered a parastratotype of the Merkine Formation in the Quaternary stratigraphic scheme of Lithuania. They are located on the right bank of the Nemunas River at Netiesos village, about $1 \mathrm{~km}$ downstream of the Netiesa Brook mouth, $3 \mathrm{~km}$ from Jonionys-Maksimonys and $6 \mathrm{~km}$ westwards of the Merkine settlement, after which the Merkine (Eemian, Mikulino, Muravian) interglacial and the formation are named.

The interglacial deposits in the Netiesos section occur at the base of the glaciofluvial terrace of the ice marginal valley of the Nemunas River. The height of the terrace is at least $20 \mathrm{~m}$. The deposits of the Netiesos palaeobasin supplement the stratotype

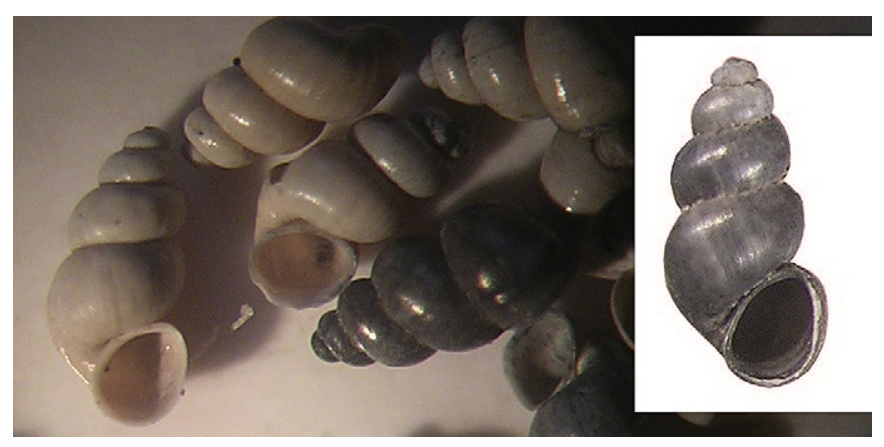

Fig. 2. Belgrandia marginata (Michaud) from section Petrovshchina in Minsk. section significantly (Kondratene, 1996). The surface of the till has traces of weathering that occurred during the Merkine interglacial. The section of the Merkine interglacial is represented in Netiesos by lake and bog deposits. Generally, they form lenses in a buried valley, the base of which is inside the till of the Medininkai glaciation (Gaigalas et al., 2005a).

The lower part of this thickness is concave and composed of lake sand with pebble and interlayers of sandy sapropelitic sediment. Upwards, the interglacial thickness contains organogenic sapropelitic sediments (gyttja) covered by a peat bed. The thickness of the interglacial deposits ranges from 5 to $7 \mathrm{~m}$. The lake-bog interglacial deposits are covered by sand-gravel deposits, locally with boulders corresponding to the early, middle and late phases of the Nemunas (Vistulian) glaciation (Gaigalas et al., 2005a,b). The total thickness of the cover is at least $12 \mathrm{~m}$. To study molluscs, 12 samples were collected from the interglacial deposits.

The numerical age of the peat cover, as determined by uranium-thorium method was found to be $105.7 \pm 10.0 \mathrm{ka}$ and $108.8 \pm 8.7 \mathrm{ka}$ (Gaigalas et al., 2005a). These dates were confirmed by dating mollusca from the same layer by ESR $(101.5 \pm 11.5 \mathrm{ka})$ (Gaigalas and Molodkov, 2002). The age of the molluscs dated from the lower part of the interglacial section, as determined by ESR, was $112.1 \pm 25.9 \mathrm{ka}$ (Gaigalas and Molodkov, 2002). The age of the Merkinè Interglacial determined by a thermo-luminescence method ranged from 135.9 to $103.2 \mathrm{ka}$ (Gaigalas et al., 2005b).

Malacological investigations of the deposits from the reference section of the Lithuanian Pleistocene have been carried out in the summer of 2006 with the participation of Monika Melešyte, Sigita Budenaite, and Rimantas Urbonavičius. Lake-bog deposits were described, and two malacological complexes - interglacial and periglacial - corresponding to the phase of the last Middle Pleistocene glaciation have been recognized. A full list containing 37 (8 terrestrial and 29 freshwater) mollusc taxa and their distribution are given in Sanko and Gaigalas (2007).

The interglacial complex of molluscs consists, almost solely, of freshwater species. Rare terrestrial taxa (Clausiliidae gen., Limacidae gen.) suggest that the slopes of the wetland basin were overgrown by a forest. A good confirmation of this is the occurrence of tree remains with abundant fruits of Carpinus betulus. The base of the terrestrial malacofauna in the interglacial is formed of such euryecological species as Valvata piscinalis and Bithynia tentaculata. $V$. piscinalis is a eurytopic species able to inhabit waters of glacial and interglacial basins and streams, whereas $B$. tentaculata is a thermophilic, mainly interglacial species. This is well confirmed by the distribution of the remains of both species in the section under discussion. The appearance of $B$ tentaculata shells and opercula in the deposits (samples 9 and 10) indicates the beginning of their accumulation in this interval of the interglacial thickness. The palynological and malacological diagrams (Fig. 3a and b) show the change of the climatic conditions from late glacial to interglacial in the zone where Gyraulus laevis is replaced by B. tentaculata. The freshwater fauna of the interglacial is less differentiated quantitatively. Under lacustrine conditions, the leading role was played by $B$. tentaculata. Only in the last stage of the lake and its transition into a bog, coinciding with the beginning of the climatic optimum of the Merkine Interglacial, was the assemblage dominated by Gyraulus albus.

A single shell of $B$. marginata was detected in the deposits (sample 6) corresponding to the climatic optimum of the Merkine Interglacial. This species appeared in the first half of the G. albus phase. The association of thermophilic molluscs of that time (local rise of $B$. marginata) included some species of Unioidae gen., as well as B. tentaculata and G. albus.

The periglacial complex of molluscs in the Netiesos section is represented by terrestrial species, such as Columella columella, 


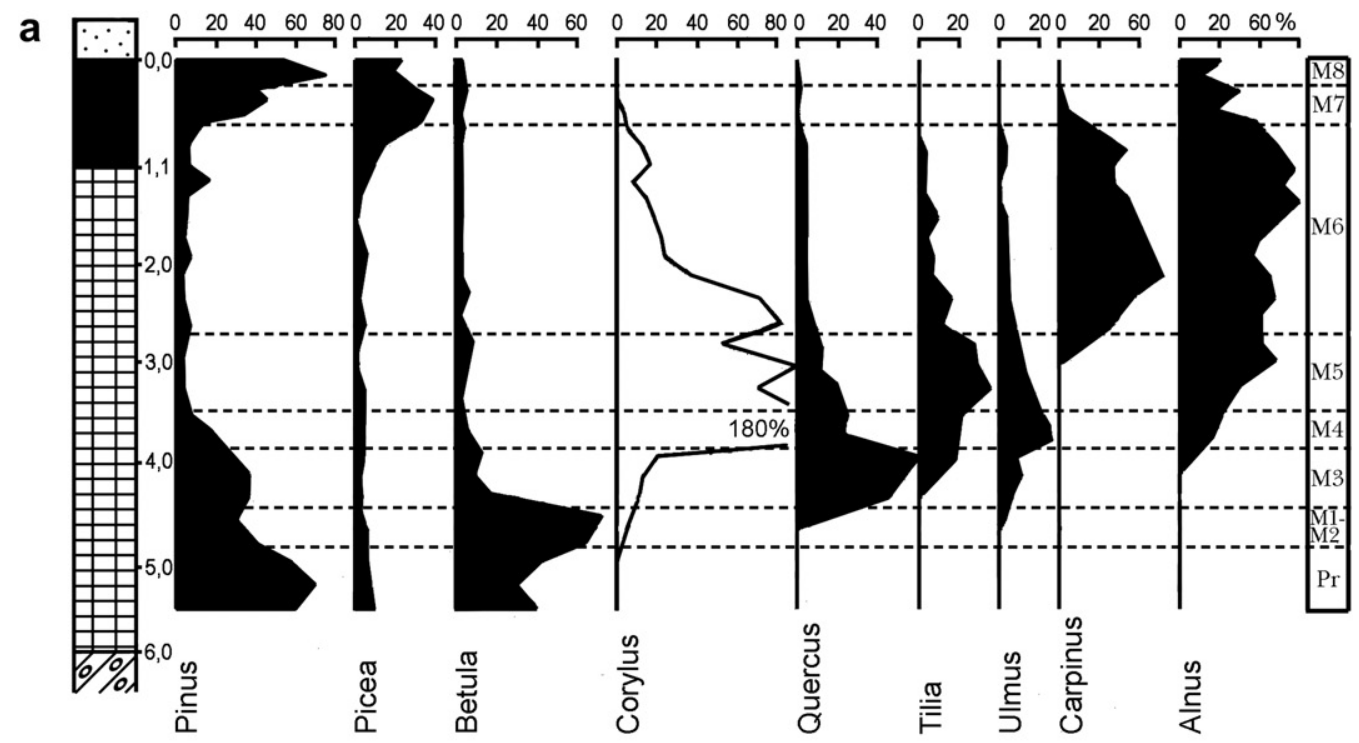

b NETESOS

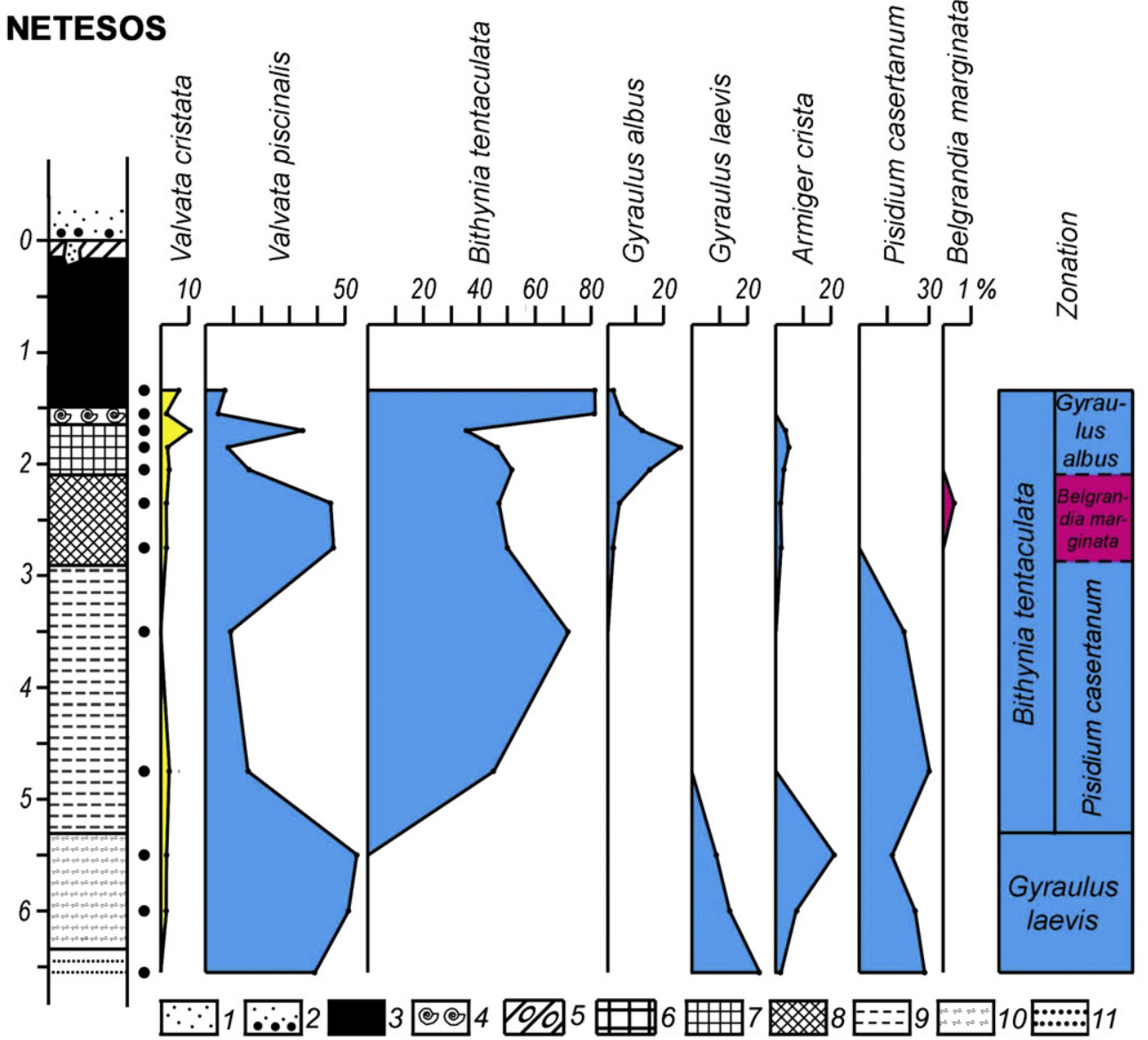

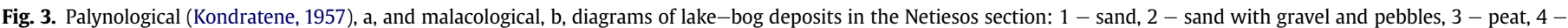

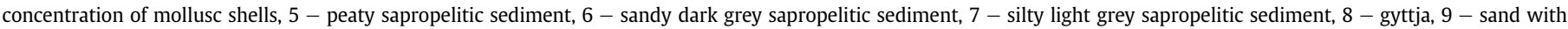
organics, 10 - sand with silt, 11 - decayed peat, 12 - till.

Vallonia tenuilabris, and Vertigo genesii. Such a combination characterises climatic conditions of a cool but not very cold stadial. All three species in the complex are absent in the present-day malacofauna of Lithuania.

\section{Malacofauna at Rumlovka}

The lacustrine deposits in Rumlowka near Grodno were discovered by Ludwik Sawicki. Based on preliminary palaeobotanic 
analyses, Srodon (1950) assigned them to the last interglacial (Muravian, Eemian). Detailed pollen studies were conducted by Yelovicheva (2001). The floral remains were studied by Velichkevich (1982), malacofauna by Voznyachuk (1959) and Sanko (1999), and mammal remains by A.N. Motuzko. Preliminary results of these studies were presented during the "Field Symposium on Quaternary Geology and Geodynamics in Belarus" (Sanko et al., 2002). Recently, lacustrine deposits from Rumlowka were subject to diatom analysis (Marciniak et al., 2007).

The lacustrine deposits of the Muravian (Eemian) Interglacial in Rumlowka (Fig. 4) are represented by marls covered by a thin bed of clayey silts, whereas the overlying sands and sands with gravels represent (according to L.N. Voznyachuk) the highest terrace of the Niemen River from the Poozerian (Vistulian) glaciation. However,
OSL-dating of the sand with gravel, executed by M. Frechen in Hannover, has given a numerical age of 54-65 ka. Hence, the sediments belong to the Middle Poozerian (Mezhanian) megastage of last glaciations, and are not correlatable with the highest river terrace of the Niemen. This is the first numerical dating of the Mezhanian megastages sediments in Belarus. The marl deposits were sampled and measured in the Rumlowka-2 section. Pollen data from the lacustrine part of the succession indicate that the section represents only the younger part of the Muravian Interglacial (Fig. 5). Shells of molluscs are met in the marl mainly in its top part, and also in overlying sandy loams and sand approximately $24 \mathrm{~m}$ above normal water level in the Neiman River.

Preliminary malacofaunal data were presented in Sanko et al. (2002). As a result of additional study, the taxon list has increased,

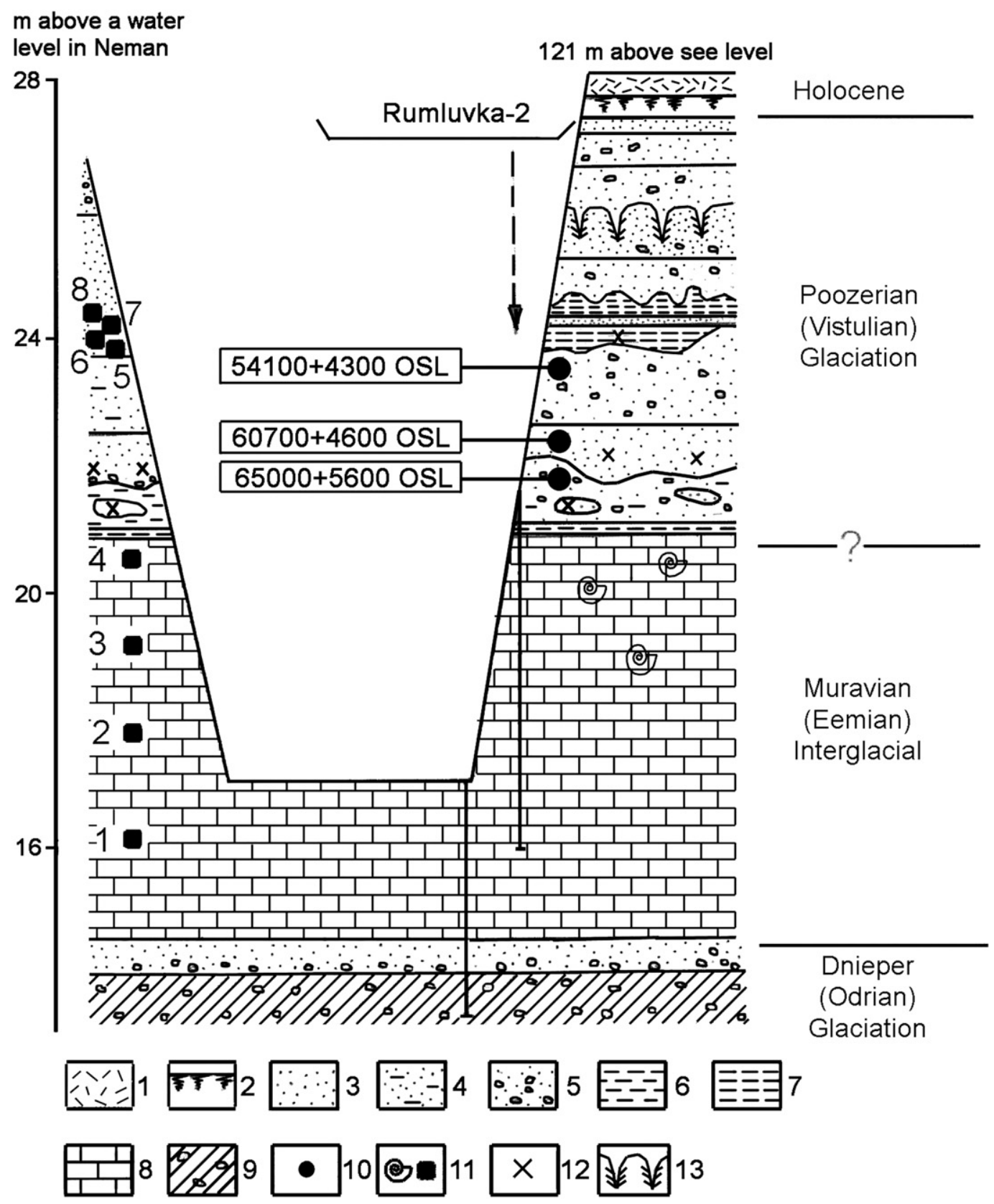

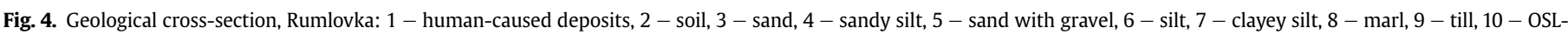
date, 11 - shells of molluscs and malacological sample, 12 - remains of mammals, 13 - frost structure. 


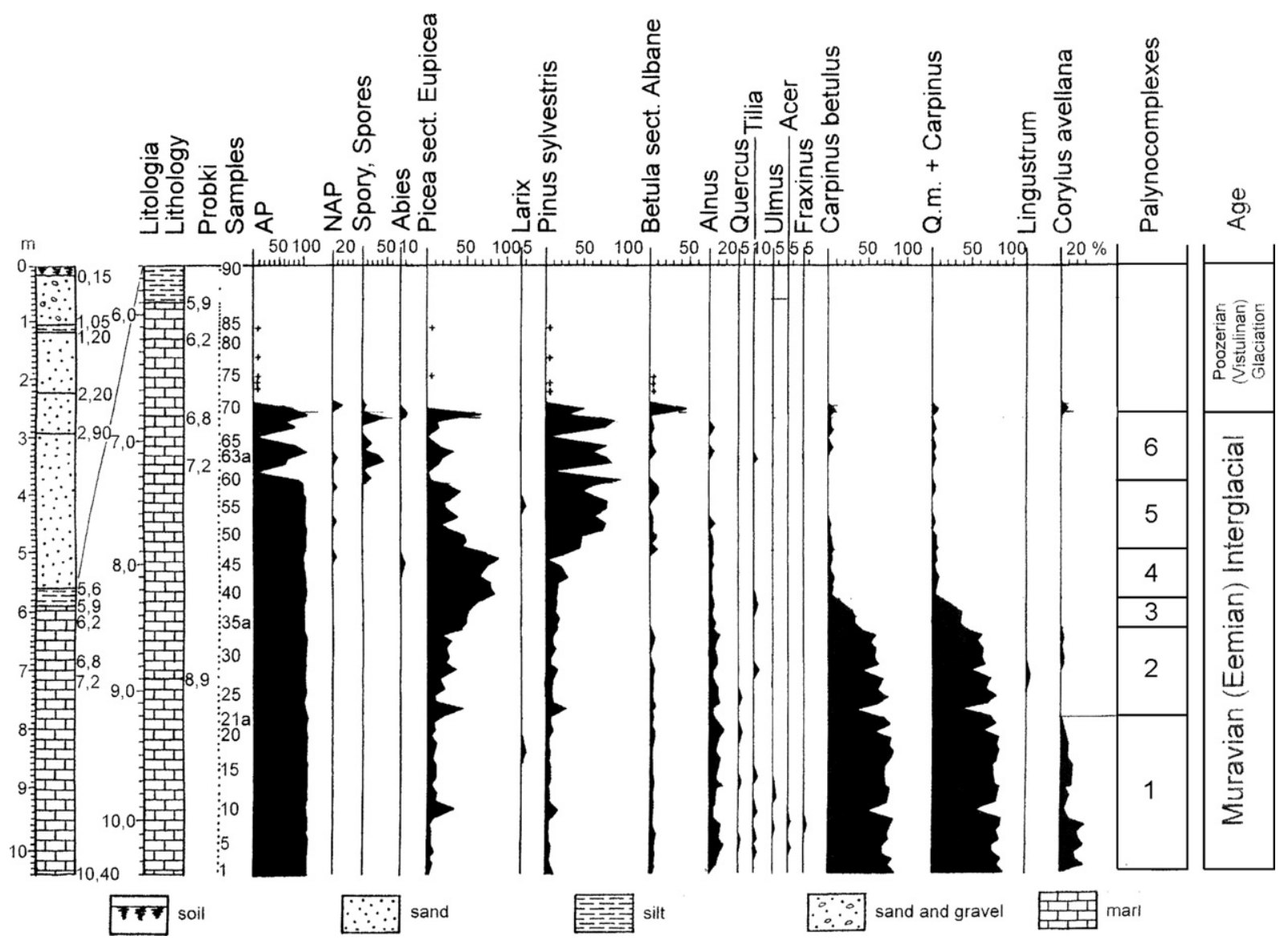

Fig. 5. Palynological diagram, Rumlovka-2.

including characteristic species of interglacial and glacial conditions (Table 1). The lesser preservation of molluscs in interglacial sediments in comparison with the glacial is caused by taphonomic conditions, mainly, the adverse geochemical environment. Nevertheless, shells of characteristic thermophilic and warm-water species are revealed in the interglacial marl. The interglacial complex includes Clausiliidae gen., B. tentaculata, G. albus, B. marginata and Unio sp. These species, as a rule, are not present in glacial fauna.

The Atlantic mollusc $B$. marginata is the most typical species of interglacial conditions. Three shells of this species are present in the uppermost interglacial marl (Fig. 6). B. marginata is present in the association with 14 ( 1 land and 13 freshwater) taxa. The ecological niches of West European species in the Rumlovka fauna are: woodland species $(0.2 \%)$, hydrophiles $(2.2 \%)$, lake molluscs (93.4\%) and river molluscs (4.2\%). V. piscinalis, B. tentaculata, Pisidium casertanum ponderosa and Unio sp. were the most frequent species. According to Skompski (1983), the species distribution was limited by a July isotherm of $18^{\circ} \mathrm{C}$.

The malacocomplex of Poozerian (Vistulian) glaciation contains indifferent and typical periglacial species. Periglacial C. columella, Vertigo parcedentata, $V$. tenuilabris represent approximately $10 \%$ of terrestrial fauna. Considering the OSL-dating, this fauna should be assigned to the oldest interstadial of the Middle Poozerian megainterstadial, the Tursk (Moershoofd) interstadial.

The change of climatic conditions from interglacial to periglacial is appreciable not only in terrestrial, but also in freshwater malacofauna. The mainly interglacial B. tentaculata was replaced by Bithynia leachi, a lower-temperature species. A similar transformation is observed in genus Gyraulus, where the mainly warm-water mollusc G. albus was replaced by the mainly cool-water species G. laevis.

\section{Malacofauna at Zhukevichi}

Lacustrine deposits with snail shells, exposed on the right bank of the Gornitsa River (a left tributary of the Neiman), $300 \mathrm{~m}$ upstream from the mouth (Fig. 7), were found and studied by Polish geologists and palaeontologists (Halicki and Sawicki, 1935; Srodon, 1950; Urbanski, 1951). These researchers correlated lacustrine deposits with the Muravian Interglacial based on spore- and pollen and malacological data. The section has been studied by many Quaternary geologists and palaeontologists from Belarus and Russia. It has been recognized during this time, that not only Muravian, but also Dnieper (Upper Saalian) layers are presented in the lacustrine thickness. The Zhukevichi section is of great importance for the study of the Late-Dnieper and Muravian intervals in Belarus, because of its well-studied and representative palaeontological materials (palynoflora, seed flora, diatoms, mammal fauna, molluscs, ostracodes).

According to palynological data (Voznyachuk and Valchik, 1978), the lacustrine thickness may be divided into Muravian interglacial deposits and underlying Upper-Dnieper deposits. Two palynozones are determined in the latest interval. The lower one reflects periglacial cold-resistant and xerophyte vegetation with sparse tree communities consisting of birch and pine. The upper zone correlates with a time of distribution of fir and fir-pine-birch sparse forests within the area of study. The upper deposits (marls and sandy silts) of the Muravian Interglacial are divided into 6 local pollen zones, corresponding to the phases of development of interglacial birch, pine, oak, broad-leaf forests with hazel, as well as hornbeam-lime and hornbeam-fir forests (Fig. 8). 
Table 1

Malacofauna at Rumlovka, specimens.

\begin{tabular}{|c|c|c|c|c|c|c|c|c|}
\hline \multirow[t]{2}{*}{ Taxon } & \multicolumn{4}{|c|}{ Muravian interglacial } & \multicolumn{4}{|c|}{ Poozerian glacial } \\
\hline & 1 & 2 & 3 & 4 & 5 & 6 & 7 & 8 \\
\hline Clausiliidae den. & & & & 1 & & & & \\
\hline Columella columella (Martens) & & & & & & & & 1 \\
\hline Vertigo parcedentata (A. Braun) & & & & & 1 & & & 2 \\
\hline Pupilla muscorum (Linnaeus) & & & & & 4 & 2 & 4 & 2 \\
\hline Vallonia tenuilabris (A. Braun) & & & & & & 1 & & \\
\hline Vertigo alpestris (Alder) & & & & & & 1 & 2 & \\
\hline Punctum pygmaeum (Draparnaud) & & & 1 & & & & & \\
\hline Limacidae gen. & & 3 & & & & & & 1 \\
\hline Succinea oblonga elongata (Sandberger) & & & & & 1 & & & \\
\hline Succinea putris (Linnaeus) & & & & & 2 & 8 & 11 & 36 \\
\hline Succinea elegans (Risso) & & & & & & & 10 & 1 \\
\hline Valvata cristata (Müller) & 4 & & & 2 & & & & \\
\hline Bithynia leachi (Sheppard) & & & & & 2 & 2 & 4 & 10 \\
\hline Lymnaea ex gr. palustris (Müller) & & & & & & 5 & 20 & 22 \\
\hline Lymnaea truncatula (Müller) & & & & & & & & 5 \\
\hline Lymnaea peregra (Müller) & & & 3 & & 7 & & & 3 \\
\hline Planorbis planorbis (Linnaeus) & & & & & & 2 & 14 & 13 \\
\hline Anisus leucostomus (Millet) & & & & & 1 & & 3 & 11 \\
\hline Gyraulus riparius (Westerlund) & & & & 8 & & & & \\
\hline Pisidium obtusale lapponicum (Sandberger) & & & & & & & 1 & 2 \\
\hline Valvata piscinalis (Müller) & 31 & 8 & 7 & 245 & 579 & 424 & 930 & 2111 \\
\hline Valvata piscinalis antiqua (Sowerby) & & & & 11 & 131 & 123 & 52 & 209 \\
\hline Bithinia tentaculata (Linnaeus) - shells & 2 & & 5 & 5 & & & & \\
\hline Bithinia tentaculata (Linnaeus) - operc. & & 4 & & 90 & & & & \\
\hline Lymnaea stagnalis (Linnaeus) & & & & & 7 & 2 & 2 & 18 \\
\hline Planorbarius corneus (Linnaeus) & & & & & & 1 & 3 & 5 \\
\hline Anisus vortex (Linnaeus) & & & & & & 2 & 2 & 1 \\
\hline Bathyomphalus contortus (Linnaeus) & & & & & 3 & & 1 & \\
\hline Gyraulus albus (Müller) & & & 3 & & & & & \\
\hline Gyraulus laevis (Alder) & & & & & 5 & 6 & 4 & 31 \\
\hline Armiger crista (Linnaeus) & & & & 2 & & & & 1 \\
\hline Sphaerium corneum (Linnaeus) & & & & & 1 & 5 & 1 & 10 \\
\hline Pisidium henslowanum (Sheppard) & & & & 1 & & 1 & 1 & 3 \\
\hline Pisidium milium (Held) & & & & & & & & 1 \\
\hline Pisidium subtruncatum (Malm) & & & & & & 7 & & 17 \\
\hline Pisidium pulchellum (Jenyns) & & & & & & & & 1 \\
\hline Pisidium casertanum ponderosa (Stelfox) & & 15 & & 46 & & & & \\
\hline Pisidium casertanum (Poli) & & & & & & 2 & 40 & 10 \\
\hline Pisidium moitessierianum (Paladilhe) & & & & 10 & & & & \\
\hline Pisidium sp. & 2 & & 3 & 10 & & 5 & & 20 \\
\hline Belgrandia marginata (Michaud) & & & & 3 & & & & \\
\hline Unio sp. & 3 & & & 16 & & & & \\
\hline Pisidium amnicum (Müller) & & & & & & 3 & 3 & 8 \\
\hline Pisidium nitidum (Jenyns) & & & & & 4 & & & \\
\hline Total & 42 & 30 & 22 & 450 & 748 & 602 & 1108 & 2555 \\
\hline
\end{tabular}

According to palaeocarpological data (F. Ju. Velichkevich, unpublished), numerous remains of cold-resistant herbs are present in the lower layers of lacustrine thickness at Zhukevichi site. They are dominated by Dryas octopetala, Polygonum viviparum, and Selaginella selaginoides, evidence of open landscapes in the vicinity of the site, resembling the landscapes of modern tundra. This flora is known as the Dryas flora of the end of Dnieper Glaciation. This flora is rare not only for Belarus, but also for Europe. Upwards in the same layer, numerous remains of tree species start to occur, including Picea obovata, which is probably its last occurrence in the Pleistocene within Belarus. Further upwards in the section, the flora changes once again, and acquires features of typical interglacial Muravian (Eemian) flora, well studied at many other sites in Belarus and neighboring European countries.

Malacological studies, carried out in Dnieper (Saalian) periglacial and Muravian (Eemian) interglacial layers at Zhukevichi, revealed a predominance of lake molluscs (see Fig. 8), belonging to the freshwater Piscinalis-fauna. This fauna is evidence of the lacustrine genesis of deposits. The shells of river molluscs are found only in one sample that indicates overflowing into the lake. Later, the lake developed as close system. In general, the Zhukevichi fauna consists of 71 taxa of terrestrial and freshwater molluscs from the Baltic sea drainage basin. An accumulation of shells of terrestrial species occurs in the bottom part. Most are representatives of coldresistant species of tundra and tundra-steppe landscapes: $C$. columella, Pupilla loessica, Pupilla densegyrata, V. tenuilabris, and $V$. genesii. The shells of freshwater molluscs of mixed composition dominate upwards in the section. The shells of both tolerant and heat-loving species occur in the marl. There are rare finds of interglacial terrestrial and freshwater species: Discus ruderatus and Planorbarius corneus in this layer. An occurrence of the West European Atlantic freshwater mollusc B. marginata is noteworthy. The ecological niches of the species include: mesophiles $(0.4 \%)$, hydrophiles (1.2\%), lake molluscs (96.8\%) and river molluscs (1.6\%). V. piscinalis, B. tentaculata, G. albus and Unio sp. were the most frequent. The appearance of $B$. marginata in the Zhukevichi malacofauna occurred in an optimum of the Muravian interglacial, along with oak and oak-lime woods and a rich understorey with hazel (see Fig. 8). 

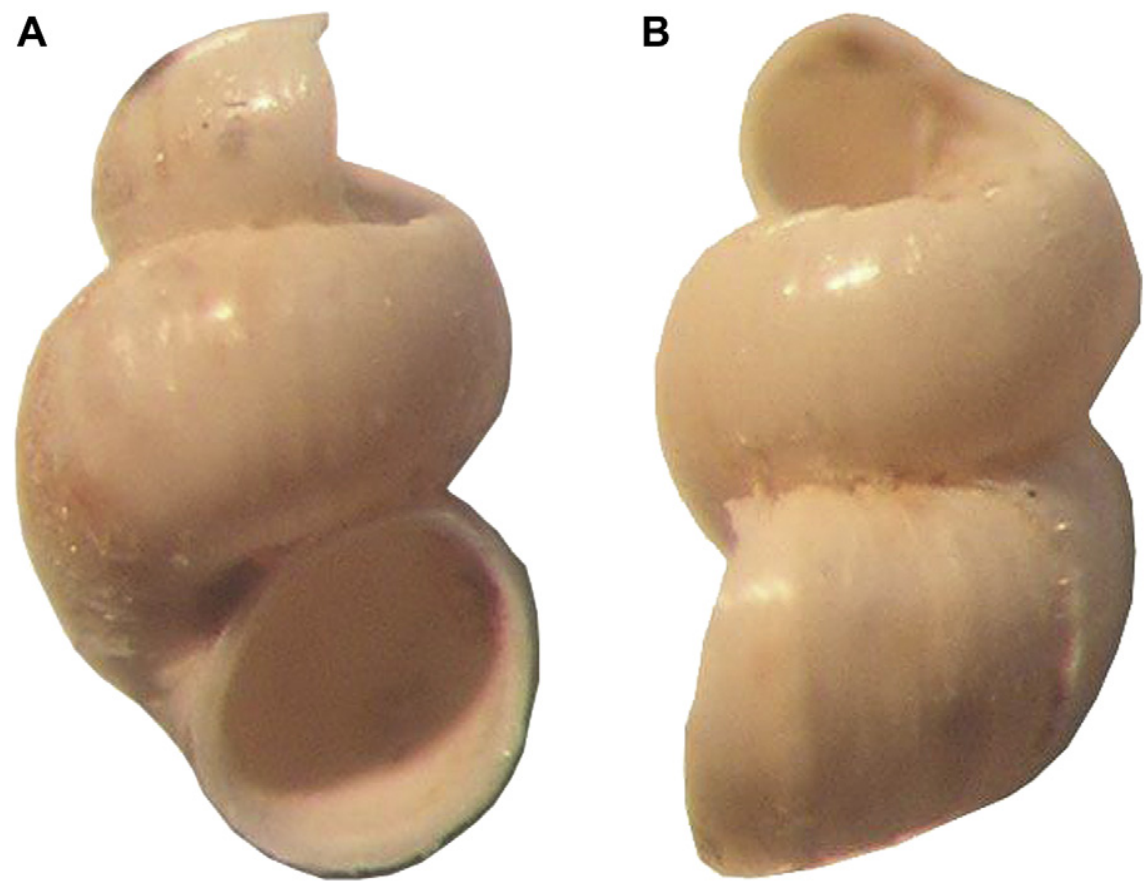

Fig. 6. Belgrandia marginata (Michaud) from Muravian (Eemian) interglacial sediments, Rumlovka. A: operculum view; B: side view.

Lacustrine deposits, similar to those outcropping at the Zhukevichi site, occur in the Upper Pleistocene section along the lower reach of the Gornitsa River. Most probably, the Zhukevichi and Kovaltsy sections contain sediments deposited in different parts of the same lake, which may be called the Gornitsa Lake. The length of this lake may have been more than $1 \mathrm{~km}$ : marls are exposed in the valley of a nameless stream $300 \mathrm{~m}$ eastward from the Zhukevichi outcrop, and they are also found in a borehole at Kovaltsy village. Palynological, palaeocarpological, malacological and teriofaunistic data argue for the Late Muravian age of deposits and lacustrine genesis. The lake had no connection with the river during this time. Local erosion processes, caused by active hydrodynamic conditions, took place during the Dnieper Late Glacial. These processes resulted in accumulation of sand, gravel, and shells of rheophile molluscs.

\section{Malacofaunaat Belynovichi}

A total of 39 shells of B. marginata were found in sediments of borehole TL-48 (Belynovichi) in the Mogilev area. Malacofauna includes 18 taxa belonging to the Black Sea drainage basin. The sediments with shells of molluscs are deposited on a moraine and are overlain by periglacial sediments (sand, sandy loam). The section is beyond the maximum of the Last (Poozerian) glacier. Shells are more or less regularly distributed (Fig. 9). B. marginata does not exceed 2\%. B. marginata together with Dreissena polymorpha, Carychium tridentatum, and G. albus form a complex of thermophilic species from the Black Sea drainage. The Ponto-Caspian mollusc $D$. polymorpha had an especially large concentration in the fossil malacofauna, almost never below $60 \%$. This concentration of a warm-water mollusc indicates warm climate, corresponding to an Interglacial optimum. This mollusc has penetrated to Belarus only once in the Pleistocene, during the Muravian Interglacial (Sanko, 1999). Therefore, the age of fauna with B. marginata is estimated as Muravian. Humans caused a wide circulation of D. polymorpha to northern Europe in the Holocene and even caused penetration of this Ponto-Caspian species into North America.

The freshwater molluscs penetrated the drainage basin of the Upper Dnieper in an optimum of the Last Interglacial from the south (the Black Sea Coast), and from the west (the Atlantic Coast of Western Europe). This phenomenon indicates the warmer and
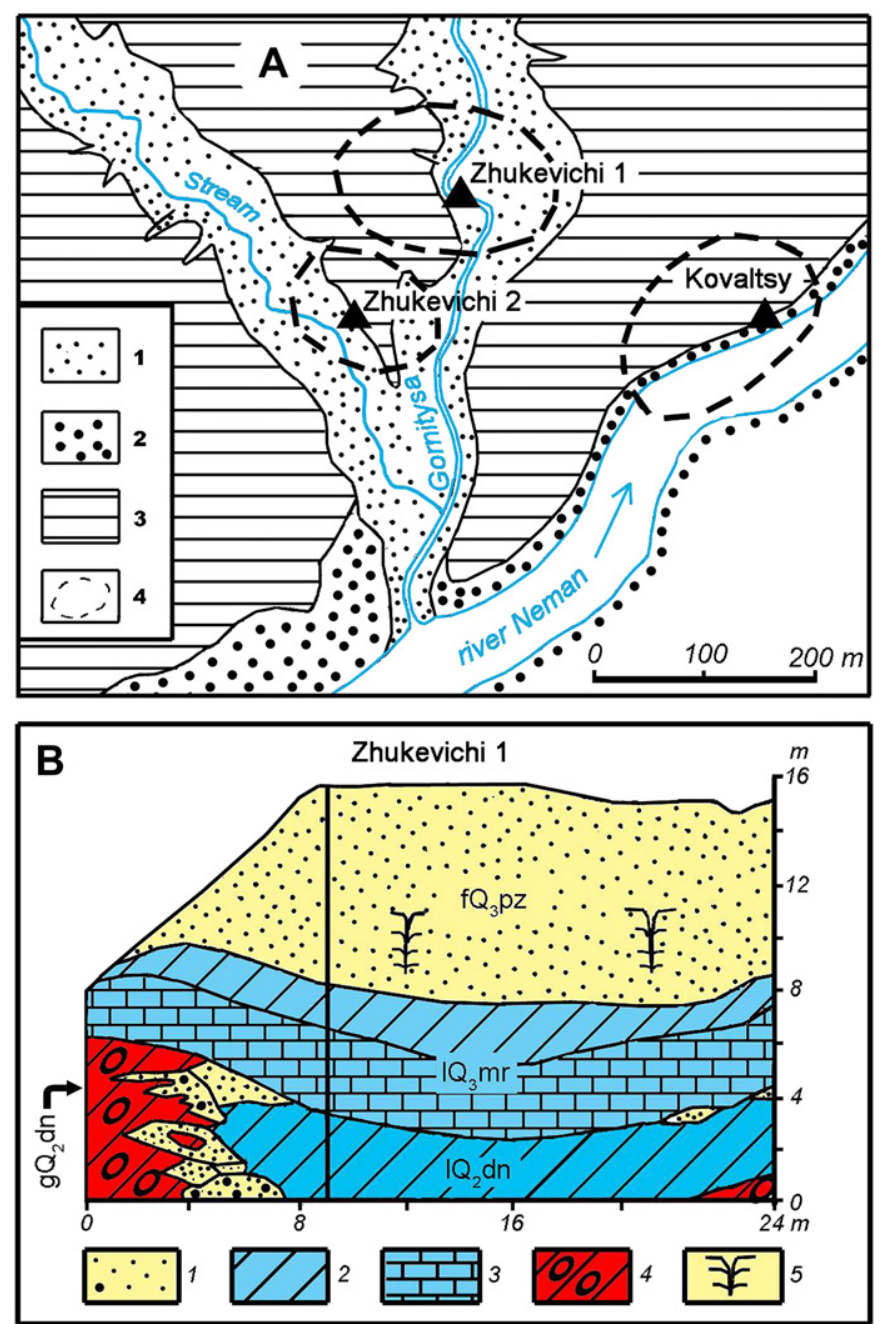

Fig. 7. A - Geomorphological sketch of the Neiman valley in the vicinity of Zhukevichi: 1 - tributary valley, 2 - Neiman valley, 3 - plateau, 4 - Eemian lakes. B - Geological section along the right bank of the river Gornitsa: 1 - sand, 2 - loam and loamy sand, 3 - marl, 4 - till, 5 - frost structure. 


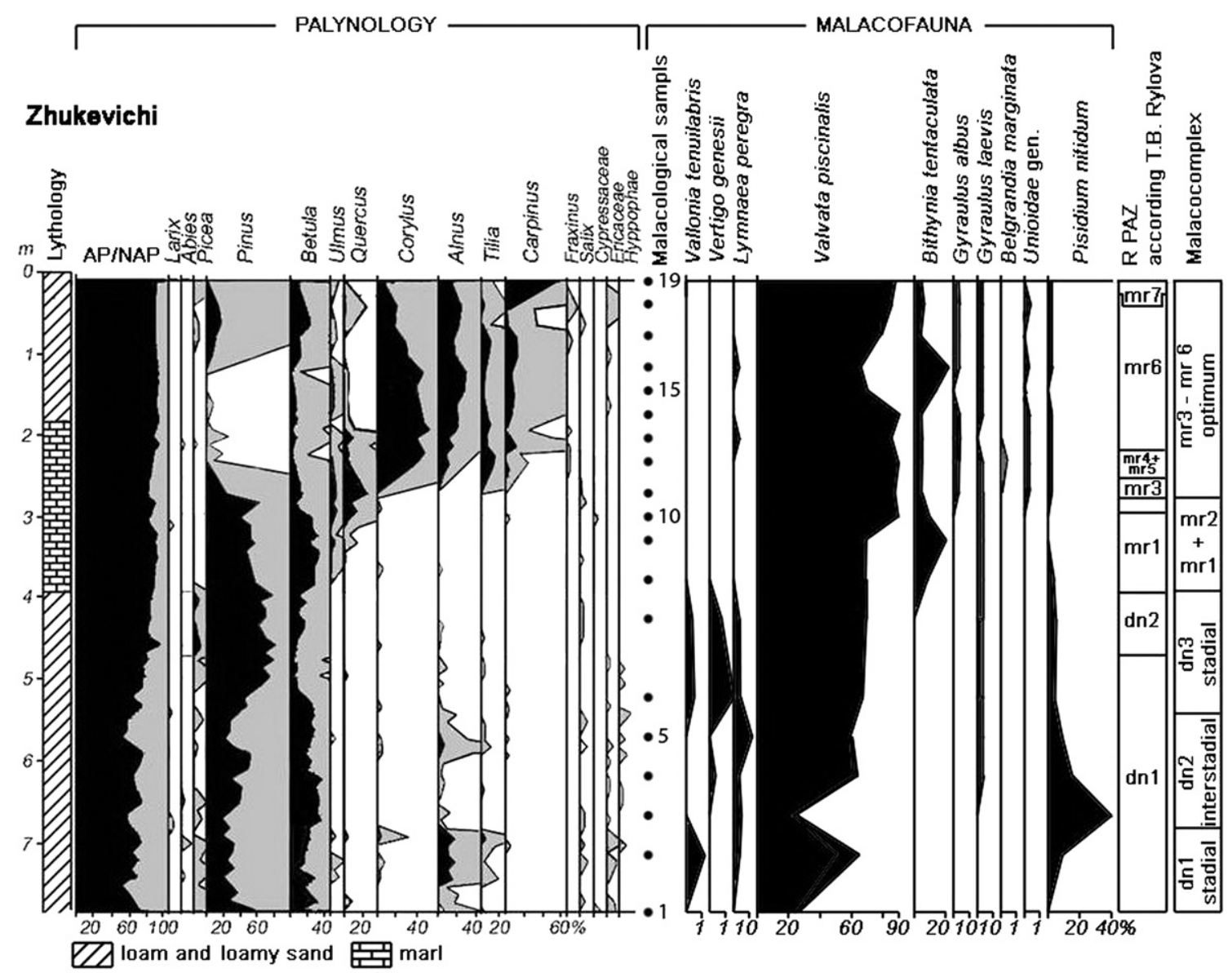

Fig. 8. Combined palynological and malacological diagram of Zhukevichi-1 deposits.

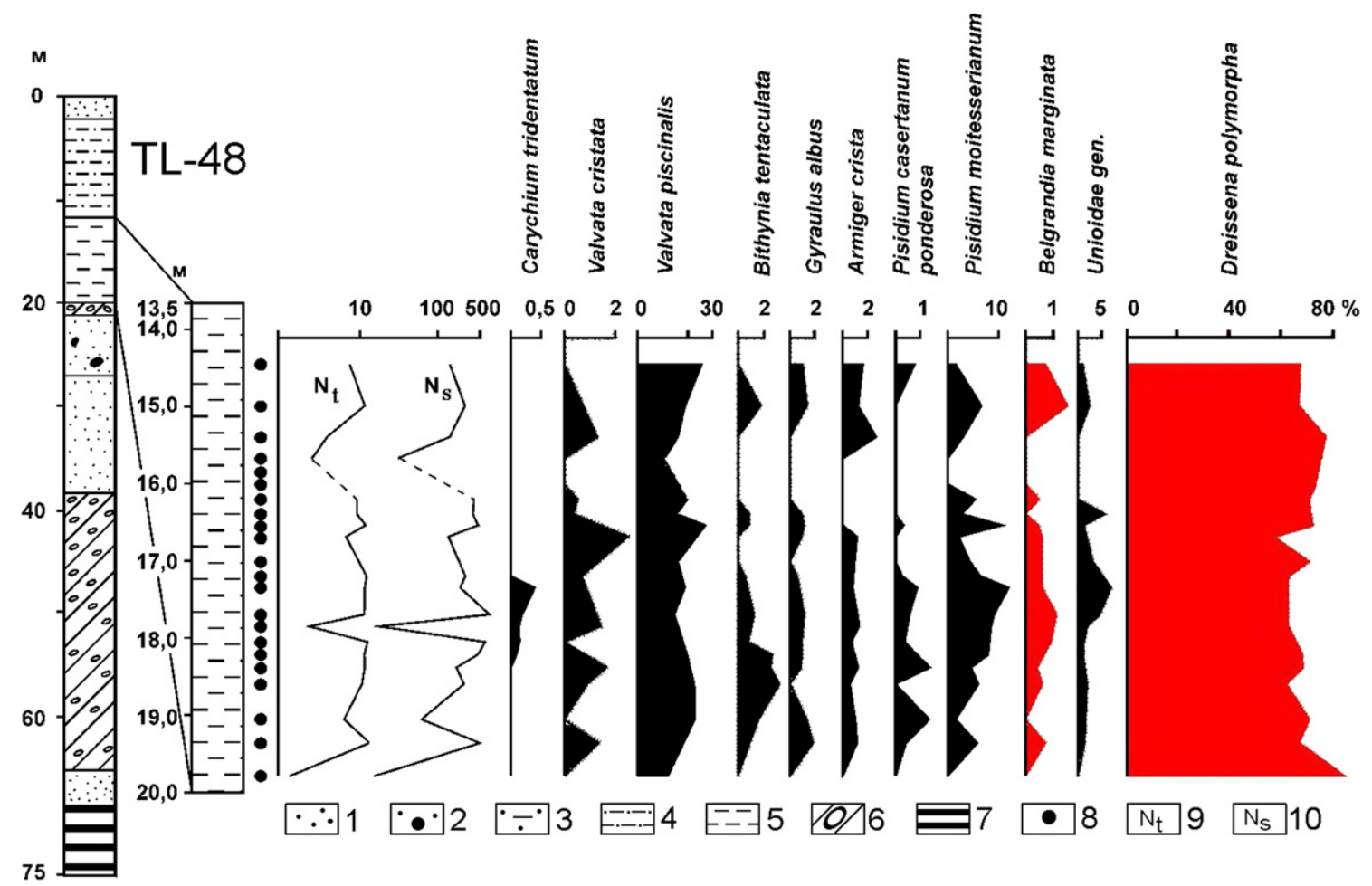

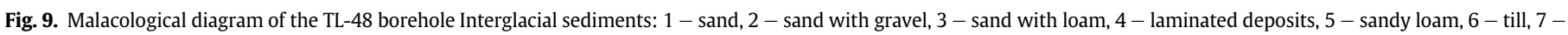
pre-Quaternary deposits, 8 - sample for malacological analysis, 9 - number of taxa, 10 - number of specimens. 
Table 2

Malacofauna at Petrovshchina in Minsk, specimens.

\begin{tabular}{|c|c|c|c|c|c|c|c|c|c|c|}
\hline Taxon|sample & 1 & 2 & 3 & 4 & 5 & 6 & 7 & 8 & 9 & 10 \\
\hline Limacidae gen. & 1 & 3 & & & & & & & & \\
\hline Vertigo sp. & & & & & & 1 & & & & \\
\hline Valvata cristata (Müller) & 25 & 21 & 13 & 1 & 13 & 15 & 14 & 102 & 137 & 55 \\
\hline Lymnaea e gr. peregra (Linnaeus) & & 1 & & & & & & 1 & & \\
\hline Sygmentina nitida (Müller) & 3 & & & & & & & 3 & 1 & \\
\hline Valvata piscinalis (Müller) & 114 & 703 & 207 & 27 & 88 & 750 & 637 & 477 & 148 & 210 \\
\hline Bithynia tentaculata (Linnaeus) - operculum & 3 & 21 & 9 & 1 & 5 & 32 & 38 & 65 & 22 & 13 \\
\hline Bithynia tentaculata (Linnaeus) - shells & 3 & 50 & 42 & 4 & 7 & 46 & 54 & 101 & 97 & 100 \\
\hline Physa fontinalis (Linnaeus) & & & & & 1 & & & & & \\
\hline Lymnaea stagnalis (Linnaeus) & & 2 & 1 & & 2 & & 1 & & 2 & 2 \\
\hline Lymnaea auricularia (Linnaeus) & & & & & & & & 2 & & 2 \\
\hline Anisus vortex (Linnaeus) & & 1 & & & & & 2 & & & \\
\hline Gyraulus albus (Müller) & 2 & 12 & 7 & 2 & & 15 & 17 & 11 & 8 & 9 \\
\hline Gyraulus laevis (Alder) & 8 & 7 & 1 & & & & & & & \\
\hline Armiger crista (Linnaeus) & 8 & 32 & 17 & 1 & 4 & 15 & 18 & 47 & 56 & 33 \\
\hline Acroloxus lacustris (Linnaeus) & 1 & & & & 1 & 1 & & & & \\
\hline Pisidium henslowanum (Sheppard) & & 2 & 1 & 1 & 2 & 12 & 6 & 19 & 8 & 1 \\
\hline Pisidium milium (Held) & & & & & & & & 1 & & \\
\hline Pisidium subtruncatum (Malm) & & 3 & 2 & & & & 10 & 1 & & \\
\hline Pisidium casertanum ponderosa (Stelfox) & 19 & 18 & 15 & 3 & 4 & 25 & 37 & 15 & 13 & 9 \\
\hline Pisidium moitessierianum (Paladilhe) & 15 & 115 & 63 & 1 & 7 & 90 & 88 & 61 & 5 & 20 \\
\hline Belgrandia marginata (Michaud) & & 1 & 1 & 1 & 2 & 12 & 6 & 19 & 8 & 1 \\
\hline Uniaceae gen. & & 5 & 2 & & & 5 & 10 & 1 & & \\
\hline Pisidium amnicum (Müller) & & & & & & 1 & 1 & & & \\
\hline Pisidium nitidum (Jenyns) & 10 & 5 & 4 & & & & 2 & 3 & 6 & 8 \\
\hline Dreissena polymorpha (Pallas) & & 7 & 103 & 60 & 51 & 545 & 515 & 610 & 175 & 158 \\
\hline Total & 212 & 1009 & 488 & 102 & 187 & 1565 & 1456 & 1539 & 686 & 621 \\
\hline
\end{tabular}

damp climatic conditions of the Muravian Interglacial of Belarus in comparison with modern climate and even the Holocene optimum. Interpolating climatic conditions of northern France where the examined species lives to Middle Belarus suggests average temperatures for January of $1-5^{\circ} \mathrm{C}$ and average July temperatures of $17-22{ }^{\circ} \mathrm{C}$.

\section{Malacofauna Petrovshchina in Minsk}

Organic sediments with shells of $B$. marginata were found during building of a line of the Underground along Dzerzhinsky Prospect, at its crossing of a valley of an ephemeral stream near Petrovshchina, a southwestern suburb of Minsk. They lie in a lens over fluvioglacial sediment and a moraine, and are covered by cover loess and loess-like loams.

Shells of molluscs are present in sandy loams and gyttja. In total, 26 taxa are present, including 2 terrestrial and 24 freshwater ones (Table 2). The fauna basis is formed by lacustrine species, including those capable of living in flowing and stagnant water. There are species of low energy flows, indicative of lacustrine currents. Current energy can be estimated by the Bithynia-index, related to the number of opercula of $B$. tentaculata, with increasing values indicating greater energy and consequent transport. The value of the Bithynia-index in the lower part of sediments is equal to 1 , implying complete absence of current movement. In the overlying sandy loam, the index is 2.4 , and in the gyttja from 1.4 to 7.7 . This indicates substantial variability of flow in the lake, most likely a function of precipitation.

The age of fauna and sediments is defined by the presence of the two species $B$. marginata and D. polymorpha (Fig. 10), indicating a Muravian age (Sanko, 1999). Its wide and expanding distribution in the Holocene in Europe and North America, particularly during historical time, is caused by human migration. In essence, $D$. polymorpha is a synantropic water mollusc. It is not excluded, therefore, that this species was inadvertently transported by humans to Belarus across Pra-Dnieper in Muravian (Eemian) time.
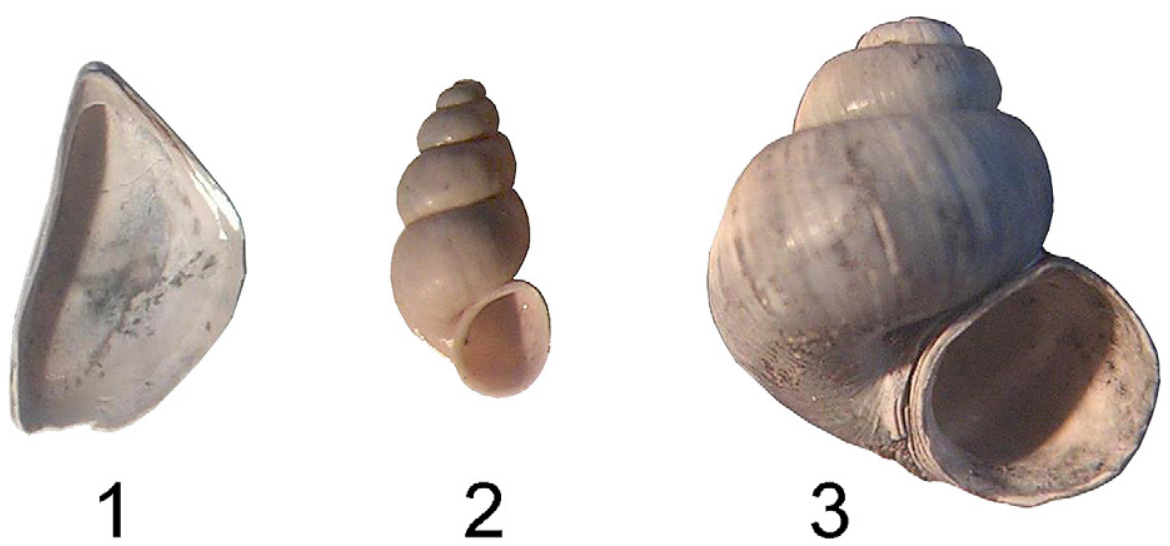

Fig. 10. Shells of Dreissena polymorpha (Pallas) (1), Belgrandia marginata (Michaud) (2) and Valvata piscinalis (Muller) (3) from sediments of Petrovshchina section, Minsk. 


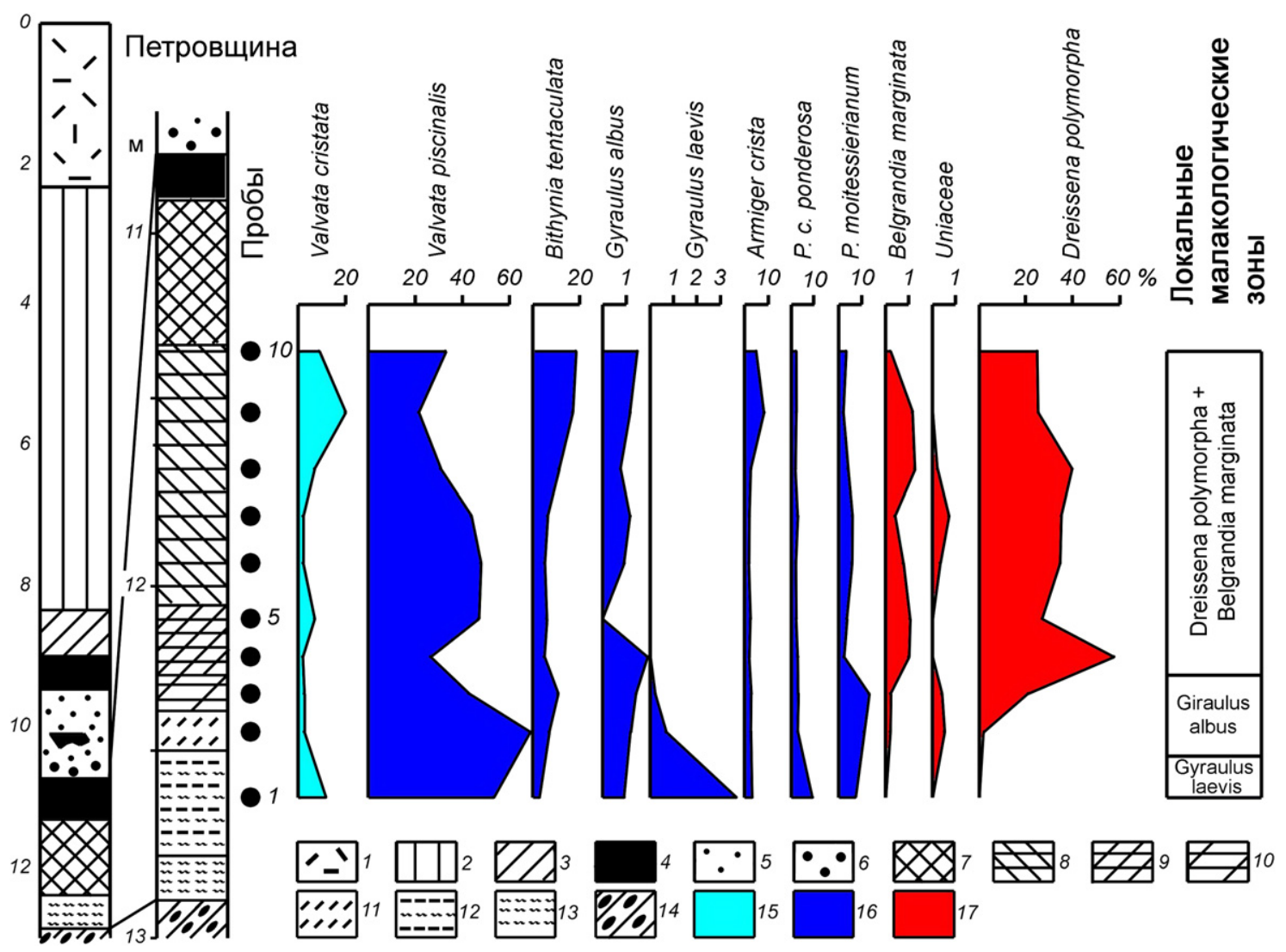

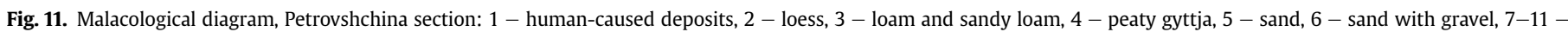
gyttja, 12 - silt, 13 - silty loam, 14 - till, 15 - hydrophiles, 16 - lacustrine molluscs, 17 - river molluscs.

The malacological diagram illustrates the distribution of basic elements of the fauna (Fig. 11). The local zone G. laevis is correlated to the Early Muravian Interglacial, and the local malacologial zones G. albus and D. polymorpha $+B$. marginata correspond to an optimum Muravian (Eemian) interglacial. The freshwater fauna, which is a part of these zones, is the warmest-water assemblage to occupy Belarus during the Quaternary.

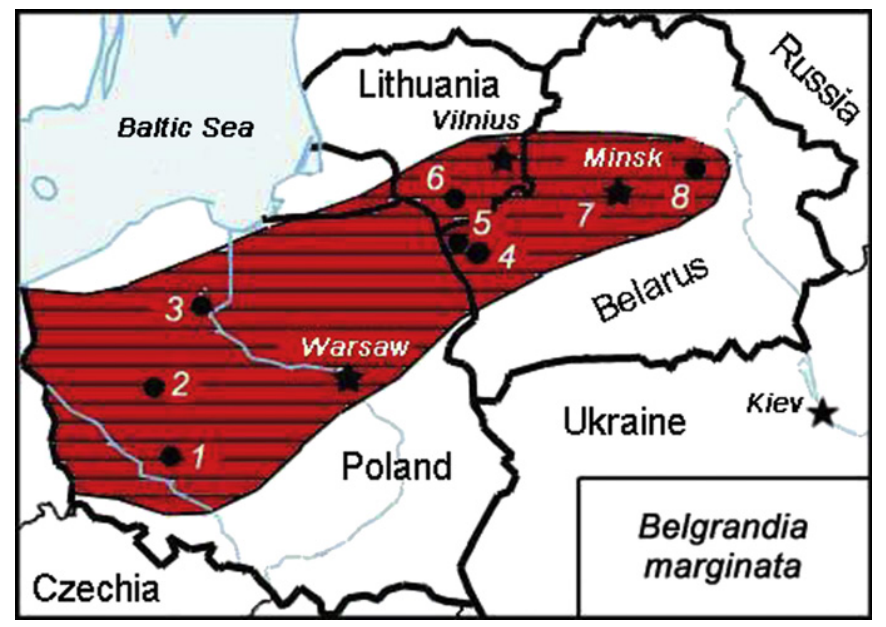

Fig. 12. Distribution of Belgrandia marginata (Michaud) in Poland, Belarus and Lithuaniain Muravian (Eemian) interglacial: 1 - Žmigród, 2 - Szelag, 3 - Brachlewo, 4 Zhukevichi, 5 - Rumlovka, 6 - Netiesos, 7 - Petrovshchina, 8 - Belynovichi.

\section{Conclusion}

Two approaches - palaeoclimatic and stratigraphic - were applied to study the species of $B$. marginata. The palaeoclimatic significance of the species is due to its relationship with optimal climatic conditions of the last interglacial in Poland, Belarus, and Lithuania. According to Velichko (1973), the climatic optimum of the Mikulino (Eemian) interglacial on the Russian Plain corresponded to the most extreme climatic indices for the whole Quaternary. This conclusion recently has been confirmed. According to Skompski (1983), the spread of $B$. marginata northwards during the Polish Eemian was limited by the July isotherm of $18^{\circ} \mathrm{C}$. On the other hand, the penetration of the Atlantic mollusc far eastwards indicates the significant influence of the Atlantic marine climate during the Eemian interglacial. This influence, most probably, was stronger than that during the Holocene optimum or at present time. The stratigraphic or, to be more precise, climatostratigraphic role of the species under discussion in the area of Poland, Belarus and Lithuania is, first of all, related to its double peculiarity as a migrant species and as an interglacial relict. B. marginata appeared here in the Quaternary malacofauna only once, during the warmest Eemian (Merkinè) Interglacial, and it was not observed in any other Quaternary malacofauna in the region, defining its climato-stratigraphic role. In Western Europe, where $B$. marginata is observed in malacofaunas of several interglaciations, its climato-stratigraphic significance is weaker.

The occurrence of $B$. marginata in malacofauna enables identification of the deposits corresponding to the climatic optimum of the last interglacial. In order to divide the deposits in the section according to the malacofaunal data, the whole complex of molluscs 
should also be taken into account. The findings of fossil shells of B. marginata in Poland, Belarus, and Lithuania allowed stratigraphic correlation of deposits. Presently, the deposits from all seven sites are well correlated (Fig. 12). Further finds of B. marginata should be useful for stratigraphic identification of deposits.

\section{References}

Gaigalas, A., Arslanov, Kh.A., Maksimov, F.E., Kuznetsov, V.Yu., Chernov, S.B. Melesyte, M., 2005a. Results of uranium-thorium isochron dating of Netiesos peat-bog in South Lithuania. Geologija 51, 29-38.

Gaigalas, A., Fedorowicz, S., Melesyte, M., 2005b. TL dates of aquatic sandy sediments of Middle-Upper Pleistocene in Lithuania. Geologija 51, 39-49.

Gaigalas, A., Molodkov, A., 2002. ESR ages of three Lithuanian Mid-Late Pleistocene Interglacials: methodical and stratigraphical approach. Geochronometria 21, 57-64.

Halicki, B., Sawicki, L., 1935. Report on investigation about Quaternary stratigraphy in valley of Middle Neiman. Posiedzenie Naukowe. Państwowego Instytutu Geologicznego, Warszawa, vol. 43, pp. 3-6 (in Polish).

Kondratene, O.P. (Zinkevichute, O.), 1957. Interglacial formation of south Lithuania Proceedings of Regional Meeting on Quaternary Sediments Studying of Baltic and Belarus. vol. 4, Vilnius, pp. 139-152 (in Russian).

Kondratene, O.P., 1996. Quaternary Stratigraphy and Palaeogeography of Lithuania According to Palaeobotanic Data. Academia, Vilnius, 213 p (in Russian)

Marciniak, B., Yelovicheva, Ya., Lindner, L., Sanko, A., 2007. Site of lake deposits of Muravian (Eemian) interglacial in Rumlovka near Grodno (Belarus). Biuletyn Panstwowego Instytutu Geologicznego, Warszawa, vol. 45, pp. 75-86 (in Polish).

Meijer, T., Preece, R.C., 1996. Malacological evidence relating to the stratigraphical position of the Cromerian. In: Turner, C. (Ed.), The Early Middle Pleistocene in Europe. Balkema, Rotterdam, pp. 53-82.

Niezabitowski, E.L., 1929. Interglacial in Szelag near Poznan. Sprawozdanie Komisji Fizjograficznej PAU, Krakow, vol. 63, pp. 51-70 (in Polish).
Sanko, A.F., 1999. Fauna of Molluscs of the Belarus Glaciopleistocene and Holocene. Institute of Geological Sciences NAS of Belarus, Minsk, 103 pp (in Russian).

Sanko, A., 2004. Atlantic mollusc Belgrandia marginata from Muravian (Eemian) fauna of Belarus. Reconstruction of Quaternary Palaeoclimate and Palaeoenvironments and Their Abrupt Changes, Abstracts and Field Trip Guidebook, 29 September-2 October 2004. Bialowieza, Poland, Warsaw, pp. 58-59.

Sanko, A., Gaigalas, A., 2007. First finding of Belgrandia marginata (Michaud) in the Lithuanian Quaternary malacofauna. Geologija 60, 83-89.

Sanko, A., Yelovicheva, Ya., Motuzko, A., Velichkevich, F., 2002. Stop 7. Muravian (Eemian) lacustrine deposits at Rumlovka. Field Symposium on Quaternary Geology and Geodynamics in Belarus, May 20-25, 2002. Excursion Guide. Minsk, pp. 46-52.

Skompski, S., 1983. Molluscs from Eemian interglacial in Zmigrod near Barycza, Kwartar. Geologica 27, 151-188 (in Polish).

Srodon, A., 1950. Development of vegetation near Grodno during Last Interglacial. Acta Geologica Polonica 1, 365-390 (in Polish).

Urbanski, J., 1951. Interglacial fauna molluscs (Mollusca) in Zhukevichi near Grodno, Warszawa. Acta Geologica Polonica 2, 102-127 (in Polish).

Velichkevich, F.Yu., 1982. Pleistocene Floras of Glacial Regions of East-European Plain. Publishing office "Science and Technics" (Nauka i technika), Minsk, 239 pp (in Russian).

Velichko, A.A., 1973. Natural Process in the Pleistocene. Publishing office "Nauka" (Science), Moscow, 256 pp (in Russian).

Voznyachuk, L.N., 1959. Conditions Deposition of Riss-Wurm Deposits in Grodno Region and Adjacent Area of Lithuania and Poland, vol. 4. News of Academy of Sciernces, Belarus SSR, Minsk, pp. 108-126 (in Belarus).

Voznyachuk, L.N., Valchik, M.A., 1978. Morphology, A Structure and A History of the Neiman Valley Development in Neopleistocene and Holocene. Publishing office "Science and Technics" (Nauka i technika), Minsk, 211 pp (in Russian).

Yelovicheva, Ya.K., 2001. Evolution of the Quaternary Natural Environment of Belarus (According to Palynological Data). Publishing office "Belsens", Minsk, 292 pp (in Russian). 